\title{
Family physicians' professional standards in the decisions of medical disciplinary boards and of the Supreme Court
}

\author{
IWONA WRZEŚNIEWSKA-WALA-F
}

ORCID ID: 0000-0002-8892-5985

Department of Law, Economics, and Management of the Public Healthcare School at the Centre for Postgraduate Medical Education, Warsaw, Poland

A - Study Design, B - Data Collection, C - Statistical Analysis, D - Data Interpretation, E - Manuscript Preparation, F - Literature Search, G - Funds Collection

Summary Background. This article provides an analysis of the decisions of medical disciplinary boards (Polish "medical courts") and cassation decisions of the Supreme Court with regard to physicians' professional responsibility, focusing on family physicians and physicians employed in primary healthcare. Those rulings from which a standard can be distilled for the practice of the medical profession were selected for more detailed discussion. Such rulings are discussed in their medical and legal aspects in order to highlight the characteristics of physicians' professional responsibility. The examples discussed in this article highlight a medical practitioner's fundamental rights in proceedings before medical disciplinary boards - the right to conduct a defense - and the sentencing guidelines, including the possibility of publishing the decision in the regional disciplinary board's bulletin.

Objectives. The aim of this article is to provide valuable guidelines for the formation of a professional working standard for family doctors and those employed in primary healthcare.

Material and methods. It consists of an analysis of OSL, NSL, and SC judgments.

Results. In terms of OSL cases in Warsaw in 2016, 71\%; in 2017 it was $65.4 \%$, and in $201865 \%$ of cases. When it comes to NSL cases in 2016, 83\% involved a failure in due diligence; in 2017 it was 72\%. For SC cases, there were 7 in 2015, 18 in 2016, 25 in 2017, and 37 in 2018.

Conclusions. Judgments of medical courts create the standards for the medical profession.

Key words: physicians, family, reference standards.

Wrześniewska-Wal I. Family physicians' professional standards in the decisions of medical disciplinary boards and of the Supreme Court. Fam Med Prim Care Rev 2020; 22(2): 166-170, doi: https://doi.org/10.5114/fmpcr.2020.95326.

\section{Background}

Professional responsibility is a safeguard of medical ethics. Its defining characteristic lies in having to face the consequences of one's practice within one's profession [1]. This especially concerns the professions of public trust, such as that of a physician, the practice of which requires due diligence linked with the recipients' trust in their services. In such professions, irreproachable ethical conduct and high professional skill are indispensable [2]. For the profession of physician, the Act on the Professions of Physician and Dentist is of key importance [3], as it stipulates the basic rules of conduct for a medical practitioner. The Act lays down binding obligations for physicians and at the same time establishes the limits of their duty. It requires a medical practitioner to conduct their practice in line with the current state of medical knowledge, but relying on the methods and means available. Furthermore, it imposes a duty to comply with professional ethics and carry out due diligence in the practice of professional activities [4]. The failure to observe due diligence by a family physician or other physician providing primary healthcare may serve as the basis for a disciplinary complaint.

A medical practitioner faces responsibility for violating the law or the principles of medical ethics in the Code of Medical Ethics (CME) [5]. Proceedings against a physician under the Act on Medical Chambers [6] are initiated by a disciplinary prosecutor called the Professional Responsibility Ombudsman (Rzecznik Odpowiedzialności Zawodowej [ROZ]), appointed for a Regional Medical Chamber (Okręgowa Izba Lekarska). There are 24 Regional Medical Chambers in Poland, one of which is a Military Chamber. The cases analyzed in this work refer to decisions made by the regional disciplinary board in Warsaw (Okręgowy Sqd Lekarski w Warszawie), with jurisdiction over the largest Medical Chamber in Poland.

One of the essential elements in the analysis of medical disciplinary boards' decision-making is the procedural aspects. In accordance with the Act on Medical Chambers, disciplinary cases are heard by regional medical disciplinary boards (okręgowe sqdy lekarskie [OSLs]) in the first instance and by the Supreme Medical Disciplinary Board (Naczelny Sad Lekarski [NSL]) on appeal. In an OSL, the adjudicating panel is composed of three physicians, and the NSL decides its cases in panels of five physicians. It is also possible to take advantage of an extraordinary appeal against the NSL's decision, viz. a cassation appeal to the Supreme Court (Sqqd Najwyższy [SC]), which is staffed by professional justices. The examples discussed in this work highlight medical practitioners' fundamental rights in proceedings before medical disciplinary boards - the right to conduct a defense - and the sentencing guidelines, including the possibility of publishing the decision in the regional disciplinary board's bulletin.

In practice, the disciplinary prosecutor receives a complaint from either the patient or the patient's family, but proceedings can also be initiated ex officio. Approximately 3,000 complaints reach regional ombudsmen (OROZ) each year $(2,998$ in 2016; 3,236 in 2017; and 2,690 in 2018, $1^{\text {st }}$ semester) [7]. The ombudsman may enter an order refusing to initiate the proceedings (e.g., the case does not involve a physician) or an order to discontinue proceedings which have already been initiated if the evidence does not confirm the information submitted in the complaint. Where the ombudsman gathers relevant evidence which suggests professional misconduct by a physician, a "re- 
quest for punishment" addressed to the medical disciplinary board follows. The Act on Medical Chambers provides for two tiers of medical disciplinary boards - regional medical disciplinary boards in the first instance and the Supreme Medical Disciplinary Board on appeal. That is not the ultimate end of the proceedings, though. In line with Article 95 (1) of the Act on Medical Chambers, a binding decision by the NSL terminating the proceedings can be appealed by the parties, the Minister of Health, and the President of the Supreme Medical Council ( $\mathrm{Na}$ czelna Rada Lekarska) with a cassation appeal to the Supreme Court. It is worth emphasizing that cassations are available primarily against binding NSL decisions on the merits of the claim ("as to the substance of the case"), in convictions, acquittals, and discontinuations - where circumstances requiring such a decision are determined during the board's proceedings. No cassation appeal is available against binding NSL rulings which do not terminate the proceedings, such as appellate reversals and remands.

\section{Objectives}

The goal of this article is provide an overview, not only in statistical terms, but also using specific examples, of medical disciplinary boards' rulings and the Supreme Court's rulings related to the professional work of family doctors and doctors providing primary healthcare. At present, the working environment of doctors in general and family and primary-care practitioners in particular is less and less predictable, making it difficult to make rational decisions involving diagnosis and treatment. Thus, a medical practitioner has all the more reason to be familiar with the basic criteria for the proper practice of the profession. Being familiar with the principles of professional practice and following them in daily practice guarantees legal safety. One of the elements contributing to that safety is also being familiar with the procedures before ordinary courts and medical disciplinary boards. The goal of this article is to provide a closer look at those procedures using examples of decisions that have climbed through all of the levels: OSL, NSL, and a cassation appeal to the SC. The examples below allows one to analyze the fundamental rules in the practice of medicine: Article 4 of the Act on the Professions of Physician and Dentist and Article 8 of the CME. These provisions require doctors to proceed in line with state-of-the-art knowledge ("the current state of medical knowledge") and with due diligence. The requirement for current knowledge means that the doctor's knowledge must be up-to-date when providing health services. Additionally, it must be added that the practitioner cannot use methods deemed harmful or worthless by science or which have not been scientifically verified. In the perspective of Article 8 of the CME, physicians should carry out all diagnostics, therapy, and prevention with diligence, dedicating the necessary time to them. The diligence test does not require specialist knowledge; it is based on life experience and common sense [8]. A discussion of the above dependencies between the professional rules of conduct and the stage of disciplinary proceedings will contribute to more legal safety for physicians. Beyond a doubt, they pose valuable guidelines for the formation of a professional working standard for family doctors and those employed in primary care.

\section{Material and methods}

The analysis was conducted on statistics (it shows of the scale of the caseload) in the form of descriptions of specific cases. The first part of the analysis concerns the decisions of the OSL in Warsaw from 2016 to 2018. The Regional Medical Chamber in Warsaw covers more than 32,000 physicians and dentists, of whom 28,628 are active professionals. In the whole country, there are 192,000 physicians and dentists, more than 174,000 of whom are professionally active [9]. The source ma- terial is also significant in how it gathers a broad range of data, facilitating an evaluation of the entire diagnostic and therapeutic process, the decisions made, and the consequences of those decisions. In this part of the study, the analysis covered one of the most frequently brought charges among disciplinary prosecutors - the failure of due diligence. The cases before the OSL in Warsaw in 2016 were analyzed, and out of 55 case studies failure of due diligence was charged in 39 cases (71\%); in 2017 there were 52 cases in total, with this charge appearing in 34 (65.4\%). In 2018, out of all the cases heard by the OSL in Warsaw, 26 (65\%) involved failure of due diligence. It must be noted that despite the numbers of these cases, only a handful of decisions were handed down for charges of failure of due diligence brought against family doctors.

The analysis of NSL rulings was more challenging, as appeals from all regional boards (OSLs) are heard by this board. In 2016, out of all 161 NSL cases, failure of due diligence was the charge in $134(83 \%)$. The following year, there were 140 cases, with failure of due diligence representing $72 \%$ [10].

The cassation appeal has been available since 2010 as an extraordinary appellate remedy in medical disciplinary cases. During the first few years of the new provisions being in force, only 4-7 such appeals were brought to the SC. Currently, the number is growing: 7 in 2015; 18 in 2016; 25 in 2017; and 37 in 2018. In order to illustrate decisions relating to family and primary-care doctors, the analysis of select disciplinary decisions include only those challenged by a cassation appeal to the SC.

\section{Experimental therapy}

\section{OSL decision}

The first example deals with a case of experimental therapy. The proceedings in the case were initiated by the regional disciplinary prosecutor (OROZ), who charged a family doctor - who was treating a patient who had suffered since childhood from spondyloarthropathy and grade 2 sacroiliitis, without medical indications and without specialization in rheumatology - with conducting an antibiotic therapy which exposed the patient to unsuccessful, long-term treatment and posed health risks for the patient. The ombudsman classified the conduct as professional misconduct under Article 8 of the CME in conjunction with Article 4 of the Act on the Professions of Physician and Dentist and Article 10 of the MCE in conjunction with Article 37 of the Act on the Professions of Physician and Dentist. To clarify, these clauses mandate the physician's duty of due diligence in line with current medical knowledge and to stay within the limits of the physician's professional qualifications. If the scope of the necessary activities exceeds the practitioner's level of skill, then the doctor must refer to a more competent colleague. This does not apply to sudden or severe cases in which delay could in itself pose a threat to the patient's life or health.

On the basis of the evidence gathered, the OSL determined several facts. In August 2011, the patient reported to the defendant's private clinic for treatment of spondyloarthropathy, an inflammatory rheumatic disease, which was diagnosed in 1989 and developed into ankylosing spondylitis. The victim provided the defendant with full medical records, including hospital discharges and imaging, including sacroiliac MRI. The scans displayed chronic inflammatory lesions in the sacroiliac joints without active inflammatory characteristics, i.e., without bone-marrow edema. The defendant/doctor ordered blood tests for Chlamydia, Mycoplasma, and Borrelia antibodies. After the tests showed IgG-grade Mycoplasma antibodies, the defendant diagnosed an active Mycoplasma infection and recommended antibiotic therapy. The doctor, with the patient's consent, applied a non-standard method of antibiotic therapy over a period of 24 months, from September 2011 to September 2013, during which time the victim was alternately administered different 
antibiotics, mainly macrolides. The defendant/doctor ordered follow-up examinations, the results of which showed no significant changes. Over the 24 months of therapy, no improvement occurred, and the pain in the patient's joints intensified. During that time, the victim reported intestinal and abdominal ailments to the defendant/doctor and consulted a gastrologist, who diagnosed ulcerative colitis (UC).

In the OSL hearing, the doctor did not plead guilty to the charge. The doctor explained that in light of the diagnosis of Mycoplasma infection, he believed the proper intervention to be macrolides, which act as both antimicrobial agents and immunosuppressants. The doctor provided extensive explanations at trial, citing academic reports - mainly from American microbiologists - concerning the efficiency of macrolide antibiotic therapy for reactive arthritis caused by Chlamydia infection. Clinically speaking, the defendant was right to suspect a chronic Chlamydia infection in the victim. As the defendant went on to explain, the absence of Chlamydia antibodies in IgM and IgG grades did not at all exclude chronic infection. In his opinion, he was acting in the patient's interest using a method not widely known in Poland.

In its own analysis, the OSL considered the expert opinion of a medical professor specializing in internal medicine and laboratory diagnostics who was commissioned for the case. The expert confirmed during the disciplinary hearing that he would allow antibiotic therapy for a clinical suspicion of chronic infection, but that such therapy - according to him - should not have exceeded a period of 12 weeks. Moreover, during such therapy, the physician should monitor immunoglobulin levels and assess their changes, and in the absence of any reaction conduct a PCR test for Mycoplasma infection. The defendant/doctor had not performed such tests. Furthermore, the expert testified that he would allow a wide spectrum of antibiotics on suspicion of a different infection focus. In the expert's assessment, the use of long-term antibiotic therapy met the definition of a medical experiment.

The OSL found the doctor's explanations to be inconsistent with the evidence. The professional standard of conduct in that case was the recommendations of the Polish Society for Rheumatology and the European League Against Rheumatism, which permit targeted antibiotic therapy only in a confirmed Chlamydia infection, with PCR tests, and for a permissible duration of 3 months - not 24 months as in the case at bar. Therefore, the physician must have been conscious of applying a non-standard experimental therapy, yet still failed to obtain the patient's written consent for such therapy. Such therapies must be regarded as a medical experiment, which the expert's opinion confirmed. The OSL found the doctor guilty of professional misconduct as charged in the request and imposed the penalty of restricting medical activities for two years by prohibiting the defendant from working in open (outpatient) medicine. The doctor was allowed to practice under supervision in closed medicine (in a hospital) [11].

\section{NSL decision}

The defendant appealed the decision to the board of second instance. At that stage in the proceedings, defendants may either draft their appeals on their own or use professional legal assistance. Among other issues, the appeal alleged errors in findings of fact, procedural errors, and violations of substantive law.

In the appellant's opinion, the OSL made the erroneous finding that no improvement in the patient's health had occurred during the treatment. The lack of radical improvement was the result of circumstances beyond the doctor's control, i.e., interruptions in the therapy for reasons attributable to the patient. The appeal also noted that the expert opinion on which the OSL based its ruling was incomplete, and that the expert himself held no qualifications in the field of microbiol- ogy. Furthermore, the opinion diverged in its conclusions from numerous academic publications concerning the treatment of intracellular infections and was also inconsistent with the private opinion filed by the defendant/doctor. The penalty of restricting professional activities was also challenged due to a lack of grounds for imposing it. On the basis of such allegations, the defendant/doctor's counsel moved to modify the OSL judgment in whole and to acquit the defendant/doctor. After hearing the appeal, the NSL sustained the impugned first-instance judgment and - on the basis of Article 84 of the Act on Medical Boards - ordered that its decision be published in the bulletin of the Regional Medical Chamber [12].

\section{Cassation appeal to the SC}

The defendant's counsel lodged a cassation appeal against the Supreme Medical Disciplinary Board (NSL)'s decision, challenging it in whole. It must be borne in mind that a physician may lodge a cassation appeal to the SC only through professional counsel. Following formal acceptance for ruling, the SC rules on the merits of the cassation.

In the SC's opinion, the cassation was to be granted as regarding the allegation of making worse the defendant's procedural situation. The reason was that the NSL, on the basis of Article 84 of the Act on Medical Chambers, published the decision in the bulletin of the Regional Medical Chamber, while only the physician had appealed the OSL's decision. The nature of the institution provided for in Article 84 of the Act on Medical Chambers is similar to that of the punitive measure of publicizing the conviction and sentence in a criminal case. In the SC's opinion, publication of the decision fulfils the preventative goal of punishment, as it publicizes information thanks to which other physicians will be aware of the imposition of the penalty. However, that act also constituted a deterioration of the defendant's procedural situation. It was tantamount to a manifest and glaring prohibition of reformatio in peius (Article 434 (1) of the Code of Criminal Procedure), as the OSL had not ruled to do so, while the only appeal was lodged for the doctor's benefit. In that situation, the impugned decision was to be reversed as regarding the publication order, but with no need to issue a consequent ruling [13].

\section{Head injury in a patient with hemophilia}

\section{OSL}

The regional ombudsman charged a doctor who was on duty in a Hospital Emergency Department with having neglected due diligence in the diagnostic and therapeutic process of a hemophiliac who had suffered a craniocerebral trauma, by failing to perform diagnostic tests for intracranial injury, failing to provide a clotting factor, failing to order hospitalization, limiting the treatment to dressing of the wound on the back of the head, providing a tetanus vaccine, and discharging the patient - causing a deterioration of the patient's health (brain hemorrhage) and, in consequence, the patient's death. The OROZ classified the act as professional misconduct under Article 8 of the MCE in conjunction with Article 4 of the Act on the Professions of Physician and Dentist. On the basis of the evidence in the case, the OSL determined that the patient had seen a doctor in charge of a medical rescue team, who found occipital injury following epileptic seizure. After examining the patient, the defendant/ /doctor on duty at the ED dressed the head injury. After the interview, the defendant was aware the patient had been treated at the Institute of Hematology and Transfusion for severe hemophilia. She still neither ordered nor administered the clotting factor VIII (FVIII) which the patient's mother had brought with her. The medical records show no laboratory tests or imaging. The defendant recommended pain suppressors and considered 
computer tomography, but the CT scanner was out of service. She discharged the patient, finding no grounds for hospitalization. After returning home, the patient lost consciousness, and his mother called an ambulance immediately. The medical rescue team brought the unconscious patient back to the hospital. This time, the doctor ordered a CT scan of the head and cervical spine (gradual deterioration of the picture and evolution of hemorrhagic changes). During the patient's second stay at the hospital, he was provided with the FVIII which had brought in a bag by the ambulance. The defendant/doctor consulted the Institute of Hematology and the Neurosurgery Department concerning the course of treatment. Due to the deterioration of the patient's health, he was moved to the Intensive Care Unit, where he died a few days later.

Two experts were commissioned for the case. Their opinions were unequivocal - the patient should have been given the FVIII upon arrival at the hospital, i.e., during his first stay at the ED. The decision not to administer FVIII represents a grave error by the defendant. In her explanation, the defendant admitted that she did know the patient's family had brought FVIII to the hospital, so she presumed it had been administered to the patient. In the experts' opinion, "one cannot delegate such duties" as administering medicine or a clotting factor to the patient or to the patient's family while the patient is in a healthcare institution. In the experts' assessment, in a hemophiliac patient suffering from an epileptic seizure with a resulting head injury was an absolute indication for hospitalization, whether or not he received FVIII.

The OSL did not believe the defendant had acted in line with the consultation with the Institute of Hematology. The board found that she had violated the basic standards for dealing with patients with hemophilia with a head injury following an epileptic seizure. Despite absolute indications, the defendant neither administered the clotting factor nor took any action in connection with the CT scanner malfunction. The defendant did not at all consider that an injury to the back of the head after an epileptic seizure could lead to intracranial injury, and a short observation, mainly by ED nurses, provided the basis for discharging the patient. The board found the ED doctor responsible and decided that an adequate penalty would be restricting her professional activities for eighteen months by prohibiting her employment in closed medicine [14]. The defendant's counsel appealed.

\section{NSL}

The appeal challenged the second-instance decision in whole, alleging fact-finding violations and violations of procedure and substantive law. In the counsel's opinion, the error in factual determinations consisted in the erroneous finding that the defendant refused to administer the clotting factor during the first stay at the hospital. As regards the procedure, the appeal alleged a failure to conduct analysis and to evaluate witness testimony; in the area of substantive law, it alleged a lack of analysis of the sentencing guidelines. After the hearing, the NSL modified the challenged first-instance ruling by eliminating from the description of the conduct the words "causing deterioration of the patient's health (brain hemorrhage), and, in consequence, the patient's death" and replacing them with "exposing the patient to direct danger of loss of life or serious disturbance of health". For that conduct, the NSL imposed the penalty of restricting the defendant's professional activities for eighteen months by prohibiting her from working in ED, Admissions, and Medical Rescue Teams [15].

\section{SC}

The defendant's counsel lodged a cassation appeal, alleging several issues, out of which the SC discussed the violation of the right to conduct a defense, it being absolute grounds for appeal. The right to conduct a defense is a fundamental procedural safeguard, and the way it was formulated justified it being regarded as a basic human right [16]. The cassation appellant alleged that the defendant/doctor's right to conduct a defense was violated because the counsel, for reasons outside the counsel's control, was unable to appear before the NSL on the day of the hearing. This constituted a violation of Article 6 of the Code of Criminal Procedure, Article 117(2) in conjunction with Article $117(2 a)$ of the CCP in conjunction with Article 112 of the Act on Medical Chambers and Articles 117(1) and 117(2) of the CCP, and Article 6 of the CCP in conjunction with Article 112 of the Act on Medical Chambers, by failing to notify the defendant of the appellate hearing. In view of the above legal provisions, the appellant moved to modify the NSL decision under appeal. In the hearing before the Supreme Court, the Chief Ombudsman (ROZ) moved to dismiss the cassation.

In its own analysis of the aforementioned circumstances, the SC found that the defendant's counsel had not appropriately justified her non-attendance before the NSL and, even though she had seen a doctor two days prior, she had failed to obtain a certificate of medical leave by a forensic physician. In its statement of reasons, the NSL noted that the District Court in W. alone had 10 forensic doctors on its list. However, counsel did obtain such a certification at a later date, from which it clearly follows that on the hearing day her health prevented her from appearing. Therefore, for the NSL to have conducted the case in the counsel's absence violated the defendant's right to conduct a defense. It must be emphasized, however, that in the SC's view in the case at bar the right to conduct a defense was not violated, as the case was being heard by the appellate organ, and the defendant's attendance was neither mandatory nor deemed necessary by that organ.

In evaluating the allegation, on the other hand, one must bear in mind that it was an appellate hearing; the board heard no additional evidence, and so the subject matter of the hearing was limited to the consideration of the counsel's written appeal for the issues raised therein. One must also consider that the defendant herself, being a physician, did not appear at the NSL's hearing, depriving herself of the right to conduct her own defense. It must be emphasized that, contrary to the appellant's claims, she had been duly notified of the date of the hearing, and that the notice sent to her address received two non-delivery notices [17].

\section{Discussion}

The family doctor should be guided by the principle of due diligence and should perform their duties in an appropriate manner, in the best possible way, respecting the rights of their patients. Postulates and obligations arising not only from the provisions of law, but also from the Code of Medical Ethics (Art. 56) require constant improvement of one's medical knowledge. At present, professional skills are acquired and extended through specialization. Many procedures have already been described, but they are also subject to constant modification related to the progress of and advances in medicine. These modifications are used, among other things, as guidelines and recommendations of medical societies, which are important substantive guidelines in everyday medical practice. There have also been guidelines for the management of patients with hemophilia for many years [18]. In the event of an injury, the coagulation factor is crucial. The life and health of patients with hemophilia and related hemorrhagic diathesis mainly depends on access to coagulation factor concentrates. Ordering and administering a coagulation factor is the physician's responsibility. The presence of the family in the hospital and assumptions that the factor was given to the patient is not a valid excuse for the doctor. The sooner the appropriate concentrate is injected, the sooner the bleeding will be stopped.

The basic doctor-patient relationship is based on trust, so it is extremely important to inform one's patient about the meth- 
ods of diagnosis and treatment and to obtain his/her consent. The medical and legal community points out that medical experimentation definitely goes beyond the doctor-patient relationship and requires special legal structures. One of the most important acts is the Helsinki Declaration [19], which contains the ethical principles of conducting medical experiments on people and makes a distinction between therapeutic and cognitive experimentation. The obligation to obtain informed consent is governed by paragraphs 22-26 of the Declaration [20]. However, it does not contain a definition for a medical experiment, referring to national regulations. In Poland, this is the Act on the Professions of Physician and Dentist in Arts. 21-29. According to this Act, a medical experiment is the introduction by a doctor of a new or only partially used diagnostic, therapeutic, or prophylactic methods in order to achieve a direct benefit for the health of the treated person. It can be carried out if the medical methods used so far are ineffective or if their effectiveness is insufficient. A doctor who proposes that their patient undergoes experimental therapy works in accordance with the medical duty to ensure that the risk-benefit ratio of the novel therapy is not significantly lower than the risk-potential ratio of the available therapy, if any - and if there are no available alternatives, that the likelihood and weight of the negative effects of the experimental therapy are not greater than the likelihood of disease progression [21]. The patient should be informed in advance about the goals, methods, and expected benefits or risks and about the possibility of withdrawing from participation in the experiment at any stage.

\section{Conclusions}

Nowadays, physicians need not only general rules and principles, but also detailed guidelines reflecting the daily practice of family medicine and primary care. Such guidelines in relation to the standards of practicing the medical profession can doubtless be found in the decisions of medical disciplinary boards. This article discussed only two situations in detail - one involving a head injury in a hemophiliac patient, and one with spondyloarthropathy and grade 2 sacroiliitis. For educational purposes, many such examples could and should be shown, as it is important for the awareness of the dangers to provide the stimulus for special diligence in diagnostics and therapy. The analysis of the decisions of medical disciplinary boards conducted in this article shows that the disciplinary decisions supply valuable guidelines for physicians on what is the correct exercise of their profession.

Source of funding: This work was funded from the authors' own resources.

Conflicts of interest: The authors declare no conflicts of interest.

\section{References}

1. Czarnecki P. Postępowanie dyscyplinarne wobec osób wykonujq̨cych prawnicze zawody zaufania publicznego. Warszawa: C.H. Beck; 2013 (in Polish).

2. Wyrok TK z dnia 7 maja 2002 r., sygn. SK 20/00 (OTK ZU nr 3/A/2002, poz. 29) oraz Wyrok TK z dnia 18 lutego 2004 r., sygn. P 21/02 (OTK ZU nr 2/A/2004, poz. 9) (in Polish).

3. Ustawa z 5 grudnia 1996 r. o zawodach lekarza i lekarza dentysty (Dz.U. 2008 nr 136 poz. 857 z późn. zm.) (in Polish).

4. Zielińska E. Ustawa o zawodach lekarza i lekarza dentysty. Komentarz. Warszawa: Wolters Kluwer; 2008 (in Polish).

5. Kodeks Etyki Lekarskiej z dnia 2 stycznia 2004 r., w brzmieniu nadanym uchwałą VII Nadzwyczajnego Krajowego Zjazdu Lekarzy z dnia 20 września 2003 r. [cited 15.07.2019]. Available from URL: http://www.nil.org.pl/_data/assets/pdf_file/ 0003/4764/Kodeks-Etyki-Lekarskiej.pdf (in Polish).

6. Ustawa z dnia 2 grudnia 2009 r. o izbach lekarskich (Dz.U. 2009 nr 219 poz. 1708 z późn. zm.) (in Polish).

7. Naczelna Izba Lekarska. Sprawozdania Naczelnego Rzecznika Odpowiedzialności Zawodowej Lekarzy [cited 5.07.2019]. Available from URL: https://www.nil.org.pl/struktura-nil/naczelny-rzecznik-odpowiedzialnosci-zawodowej/sprawozdania/kadencyjne-i-zjazdowe (in Polish).

8. Rek T, Hajdukiewicz D. Lekarz a prawa pacjenta. Poradnik prawny. Warszawa: Wolters Kluwer; 2016 (in Polish).

9. Centralny Rejestr Lekarzy. Zestawienie liczbowe lekarzy i lekarzy dentystów stan na dzień 7.07.2019 r. [cited 15.07.2019]. Available from URL: https://www.nil.org.pl/rejestry/centralny-rejestr-lekarzy/informacje-statystyczne (in Polish).

10. Wrześniewska-Wal I. Postępowanie przed sadami lekarskimi w praktyce. Warszawa: Wolters Kluwer; 2018 (in Polish).

11. Orzeczenie Okręgowego Sądu Lekarskiego z dnia 5 października 2016 r., sygn. akt OSL.630.73/2015 [niepublikowane] (in Polish).

12. Orzeczenie Naczelnego Sądu Lekarskiego z dnia 29 września 2018 r., sygn. akt NSL Rep. 76/OWU/17 [niepublikowane] (in Polish).

13. Wyrok SN z dnia 26 czerwca 2018 r., sygn. akt SDI 29/18, Legalis 1823859 (in Polish).

14. Orzeczenie Sądu Lekarskiego w Warszawie sygn. akt OSL.630.9/2015 [niepublikowane] (in Polish).

15. Orzeczenie Naczelnego Sądu Lekarskiego z dnia 29 września 2017 r., sygn. akt NSL Rep.138/OWU/17 [niepublikowane] (in Polish)

16. Kulesza C. Efektywność udziału obrońcy w procesie karnym w perspektywie prawnoporównawczej. Kraków: Zakamycze; 2005 (in Polish).

17. Postanowienie Sądu Najwyższego z dnia 26 czerwca 2018 r., sygn. akt. SDI 28/18, Legalis 1823858 (in Polish).

18. Zawilska K, Windyga J, Łętowska M, et al. Pomoc doraźna w nagłych zagrożeniach zdrowotnych wynikających z zaburzeń krzepnięcia krwi u chorych na hemofilię. Na Ratunek 2017; 1: 27-36.

19. Zgromadzenie Ogólne Światowego Stowarzyszenia Lekarzy (WMA), Helsinki, Finlandia, czerwiec 1964 (in Polish).

20. Czarkowski M, Różyńska J. Świadoma zgoda na udział w eksperymencie medycznym. Poradnik badacza. Warszawa: Ośrodek Bioetyki Naczelnej Rady Lekarskiej, Naczelna Izba Lekarska; 2008 (in Polish).

21. Różyńska J. Eksperyment leczniczy - dwa w jednym? Prawo Med 2016; 4: 5-30 (in Polish).

Tables: 0

Figures: 0

References: 21

Received: 20.07 .2019

Reviewed: 17.08.2019

Accepted: 14.01.2020
Address for correspondence:

Iwona Wrześniewska-Wal, MD, PhD

Zakład Prawa, Ekonomiki i Zarządzania

Szkoła Zdrowia Publicznego

Centrum Medyczne Kształcenia Podyplomowego w Warszawie

ul. Kleczewska 61/63

01-826 Warszawa, Polska

Tel.: +48 501 153-551

E-mail: iwona.wrzesniewska-wal@cmkp.edu.pl 